\title{
Fecundação In Vitro de Ovócitos Bovinos com Sêmen Submetido a Diferentes Diluidores ${ }^{1}$
}

\author{
Lia de Alencar Coelho ${ }^{2}$, César Roberto Esper ${ }^{3}$, Joaquim Mansano Garcia ${ }^{3}$, Roberta Vantini ${ }^{4}$, \\ Ivo Luis Almeida Junior ${ }^{4}$
}

\begin{abstract}
RESUMO - O objetivo deste trabalho foi avaliar a influência do diluidor do sêmen no desenvolvimento in vitro de ovócitos bovinos após a maturação e fecundação in vitro. Ejaculado de um reprodutor foi fracionado e submetido a três diluidores: Lactose/gema de ovo (LG), Citrato/gema de ovo (CG) e Tris/gema de ovo (TG). Amostras deste material foram envasadas, congeladas e estocadas em $\mathrm{N}^{2}$ e, posteriormente, descongeladas; a fração móvel foi separada por gradiente descontínuo de Percoll. A concentração espermática foi ajustada para $10 \times 10^{6} / \mathrm{mL}$ e a capacitação espermática, induzida com $10 \mu \mathrm{g} / \mathrm{mL}$ de heparina. Após 24 horas de cultura para maturação in vitro, os ovócitos, aspirados de folículos ovarianos, foram inseminados com sêmen diluído em meio TALP e, após 48 horas de cultura, os zigotos foram transferidos para gotas de meio TCM 199, com 5\% de soro fetal bovino, $5 \%$ de soro de vaca em estro e suspensão de células epiteliais do oviduto bovino, cobertas com óleo de silicone, e mantidos em cultura por nove dias. Todas as culturas foram realizadas a $38,5^{\circ} \mathrm{C}$ em atmosfera com $5 \%$ de $\mathrm{CO}_{2}$. Os dados foram analisados pelo teste do qui-quadrado e houve diferença com relação à taxa de clivagem (TC), sendo as médias de 66,0; 69,3; e 54,4\% para LG, CG e TG, respectivamente. Não houve diferença entre tratamentos com relação às taxas de mórulas/blastocistos ou de eclosão. O diluidor do sêmen não teve efeito sobre o desenvolvimento in vitro de embriões bovinos, embora a TC tenha sido afetada.
\end{abstract}

Palavras-chave: bovinos, diluidor do sêmen, embrião, fecundação in vitro, taxa de clivagem

\section{In Vitro Fertilization of Bovine Oocytes with Semen Submitted to Different Extenders}

ABSTRACT - This study investigated the effect of semen extender on in vitro development of bovine oocytes after in vitro maturation and fertilization. The ejaculate from one bull was divided in three parts which were diluted with three different extenders: Egg yolk/Lactose (EYL), Egg yolk/Citrate (EYC) and Egg yolk/Tris (EYT). Samples of semen diluted with these extenders were frozen in liquid nitrogen and, after thawing, were filtered by discontinuous Percoll gradient. The sperm concentration was adjusted to $10 \mathrm{x} 106 \mathrm{cells} / \mathrm{mL}$ and the sperm capacitation was induced with $10 \mu \mathrm{g} / \mathrm{mL}$ of heparin. After 24 hours of culture for in vitro maturation, the oocytes, aspirated from ovarian follicles, were inseminated with semen diluted in TALP medium and $48 \mathrm{~h}$ after the zigotes were transferred into droplets prepared with TCM-199 medium containing 5\% of bovine fetal serum, $5 \%$ of estrous cow serum and bovine oviduct epithelial cells in suspension under silicon oil and were further cultured of 9 days. All the cultures were performed at $38.5^{\circ} \mathrm{C}$ in $5 \% \mathrm{CO}_{2}$ in air. Data were analyzed by chi-square analysis. There was a significant difference in terms of cleavage rate (CR) with means of $66.0,69.3$ and $54.4 \%$ for EYL, EYC and EYT, respectively. There were no differences in terms of the morulae/blastocysts and hatching rates. These results suggest that the semen extender had no effect on in vitro development of bovine, even the CR have been affected.

Key Words: bovine, cleavage rate, embryo, in vitro fertilization, semen extender

\section{Introdução}

A fecundação in vitro (FIV), ou produção de embriões in vitro, é uma técnica que tem sido utilizada para estudar a fisiologia dos processos de maturação ovocitária, fecundação e desenvolvimento embrionário no estádio de pré-implantação, bem como propiciar o desenvolvimento de outras técnicas, como clonagem e transferência de genes. Além disso, a FIV tem sido utilizada para produzir indivíduos com elevado mérito genético, constituindo-se fonte alternativa de embriões em programas de transferência de embriões na espécie bovina (STROUD e MYERS, 1993; LOONEY et al., 1994; HASLER, 1996; e HANZEN e GOFFIN, 1998). Contudo, existe grande variação com relação à taxa de clivagem e produção de mórulas e blastocistos oriundos do sistema FIV (LOONEY et al., 1994; ELMILEIK et al.,

\footnotetext{
1 Projeto financiado pela FAPESP.

${ }^{2}$ Docente do Depto de Zootecnia da Fac. de Zootecnia e Eng. de Alimentos - FZEA/USP. E.mail: liac@usp.br

${ }^{3}$ Docente da Faculdade de Ciências Agrárias e Veterinárias - FCAV/UNESP. E.mail: cresper@fcav.unesp.br; jmgarcia@fcav.unesp.br

4 Técnico de laboratório da FCAV/UNESP.
} 
1995; JAAKMA, et al., 1997; FARIN et al., 1997; e CHOI, et al., 1998). Essas diferenças são determinadas por vários fatores decorrentes das etapas que constituem esse sistema, entre eles o preparo do sêmen e a indução da capacitação espermática. A capacitação in vitro requer a seleção e recuperação de espermatozóides móveis, formas normais, livres de contaminantes do plasma seminal. Têm sido utilizados diversos métodos de eliminação do plasma seminal e separação da fração móvel do sêmen diluído e descongelado, como a técnica do sedimento - swim up (PARRISH et al., 1984), separação por gradiente descontínuo de BSA (ESTIENNE et al., 1987), filtração em coluna de lã de vidro (STUBBINGS e WOSIK, 1991), técnica do sedimento - swim down (ING et al., 1991), filtração em coluna de sefadex/filtro de troca iônica (ANZAR e GRAHAM, 1993), separação por gradiente descontínuo de Percoll (AVERY e GREVE, 1995) e lavagem mediante centrifugação (JAAKMA, et al., 1997). Esses métodos, além de melhorar a viabilidade pós-descongelação do sêmen utilizado para FIV, também eliminam o diluidor do sêmen. Entretanto, pode-se observar que, mesmo utilizando alguns desses métodos, a viabilidade pós-descongelação ainda é significativamente afetada pelo diluidor do sêmen (ANZAR e GRAHAM, 1995), podendo interferir nos subseqüentes processos de fecundação e/ou desenvolvimento embrionário. Além de existir poucas informações na literatura sobre a influência do diluidor do sêmen na FIV, os trabalhos registrados são pouco conclusivos (LONERGAN et al., 1993, 1994; COELHO et al., 1996).

O presente trabalho teve como objetivo avaliar a utilização de diferentes diluidores do sêmen congelado no desenvolvimento in vitro de ovócitos bovinos maturados, fecundados e desenvolvidos in vitro.

\section{Material e Métodos}

Obtenção e preparo do sêmen para fecundação in vitro $(F I V)$

O sêmen utilizado foi processado pelo SÊMEN DO BRASIL - SEMBRA, sendo o ejaculado de um único reprodutor, fracionado e submetido a três diferentes diluidores: Lactose - gema de ovo (LG), Citrato - gema de ovo (CG) e Tris - gema de ovo (TG). Amostras deste material foram envasadas, congeladas e estocadas em nitrogênio líquido $\left(\mathrm{N}^{2}\right)$.

Para realização da FIV, utilizou-se a fração móvel do sêmen descongelado, a qual foi separada por gradiente descontínuo de Percoll. O gradiente foi constituído por soluções a $55 \%$ e a $90 \%$ de Percoll ${ }^{1}$ a $100 \%$. Para formar o gradiente, no fundo de um tubo de centrífuga contendo previamente a solução de Percoll a 55\%, adicionou-se a solução de Percoll a $90 \%$ e, sobre as duas soluções, a amostra do sêmen (uma palheta de $0,50 \mathrm{~mL}$ ) foi depositada delicadamente. Todo o conjunto foi centrifugado a $200 \mathrm{~g}$ durante 25 minutos. Após duplas lavagens, meio TALP sem cálcio e glicose, suplementado com cafeína e adicionado de sulfato de gentamicina (TALPSPERM) (COELHO, 1993), para retirada do Percoll (130 g/10 minutos), o sedimento foi ressuspenso em meio TALP-SPERM contendo heparina a $100 \mu \mathrm{g} / \mathrm{mL}$ e incubado a $38,5^{\circ} \mathrm{C}$ em atmosfera com $5 \%$ de $\mathrm{CO}_{2}$. Após 15 minutos, a suspensão de sêmen foi diluída em meio TALP com cálcio e sem glicose, suplementado com sulfato de gentamicina, hipotaurina e epinefrina (TALP-FIV) (COELHO, 1993), de modo que a concentração espermática fosse ajustada para $10 \times 10^{6}$ espermatozóides/mL e a concentração final de heparina, para $10 \mu \mathrm{g} / \mathrm{mL}$.

Obtenção dos ovócitos e das células da granulosa e maturação in vitro (MIV)

Os ovários de vacas provenientes de abatedouro foram transportados para o laboratório, à temperatura ambiente, dentro de frascos contendo solução tampão-salina-fosfato (PBS), acrescida de sulfato de gentamicina $(50 \mu \mathrm{g} / \mathrm{ml})$. No laboratório, os ovários foram lavados (2X) com solução PBS e mantidos em banho-maria, a $34-35^{\circ} \mathrm{C}$. Os ovócitos imaturos, aspirados de folículos de 3 a $8 \mathrm{~mm}$ de diâmetro, foram colocados em placas de Petri (100 mm), contendo meio TCM 199, suplementado com Hepes (25 mM), sulfato de kanamicina $(75 \mu \mathrm{g} / \mathrm{ml})$ e $10 \%$ de soro fetal bovino (SFB) (meio H-199). Sob estéreo microscópio (aumento de 10 a 60X), complexos cumulus-ovócitos (COCs) foram visualizados, lavados duas vezes em meio H-199 e colocados em cultura por 24 horas, a $38,5^{\circ} \mathrm{C}$ em atmosfera com $5 \%$ de $\mathrm{CO}_{2}$, em meio de maturação.

O meio básico de maturação foi constituído de meio TCM 199, suplementado com aditivos $(1 \mu \mathrm{g} / \mathrm{mL}$ de vitamina $B_{12}, 10 \mu \mathrm{g} / \mathrm{mL}$ de insulina, $50 \mu \mathrm{g} / \mathrm{mL}$ de álcool polivinil, $75 \mu \mathrm{g} / \mathrm{mL}$ de ácido ascórbico, $5 \mu \mathrm{g} / \mathrm{mL}$

\footnotetext{
${ }^{1}$ Pharmacia, Uppsala, Suécia.
} 
de inositol, $100 \mu \mathrm{g} / \mathrm{mL}$ de acetato de sódio e $200 \mu \mathrm{g} / \mathrm{mL}$ de glicosamina), Hepes (16,79 $\mathrm{mM})$, bicarbonato de sódio $(28,57 \mathrm{mM})$, piruvato de sódio $(2,73 \mathrm{mM})$, sulfato de kanamicina $(75 \mu \mathrm{g} / \mathrm{ml}), 5 \%$ de soro fetal bovino e $5 \%$ de soro de vaca em estro inativado (meio B-199).

Para obtenção das células da granulosa, um folículo grande ( 8 - $10 \mathrm{~mm}$ de diâmetro) foi dissecado, perfurado, invertido e, após sucessivas lavagens em meio $\mathrm{H}-199$, procedeu-se à raspagem das células em $3 \mathrm{~mL}$ de meio B-199.

A maturação in vitro foi realizada colocando-se os ovócitos imaturos (até 200 ovócitos) em placa de polipropileno $(35 \mathrm{~mm})$ contendo $1 \mathrm{~mL}$ de suspensão de células da granulosa e $2 \mathrm{~mL}$ de meio B-199, a qual permaneceu em incubadora com $5 \%$ de $\mathrm{CO}_{2}$ a $38,5^{\circ} \mathrm{C}$ durante $22-24 \mathrm{~h}$.

Fecundação e cultivo in vitro e obtenção das células epiteliais do oviduto bovino

A fecundação foi realizada em placas com microgotas de $100 \mathrm{~mL}$ de suspensão de sêmen, contendo aproximadamente 25 ovócitos por gota, e cobertas com óleo de silicone. Após 48 horas de incubação a $38,5^{\circ} \mathrm{C}$, em atmosfera com $5 \%$ de $\mathrm{CO}_{2}$, os embriões de duas e quatro células foram lavados em meio H-199 (sem soro fetal bovino) e transferidos para placas contendo microgotas compostas por $90 \mu \mathrm{lde}$ meio B199 e $2 \mu \mathrm{l}$ de suspensão de células epiteliais do oviduto bovino (CEOB), cobertas com óleo de silicone, as quais permaneceram em cultura por nove dias.

As CEOBs foram obtidas após dissecção do oviduto, raspagem e sucessivas lavagens por decantação das células em meio H-199. Após a última lavagem (meio B-199), o sedimento (CEOBs) foi ressuspenso em $5 \mathrm{~mL}$ de meio B-199 e cultivado “overnight”, com $5 \%$ de $\mathrm{CO}_{2}$ em ar a $38,5^{\circ} \mathrm{C}$. Decorridas as 24 horas, $2 \mu \mathrm{l}$ dessa suspensão foram adicionados em cada microgota de desenvolvimento.

Modelo experimental e análise estatística

Os dados referentes às taxas de clivagem (TC), mórulas e blastocistos (TMBL) e eclosão (TECL) foram analisados pelo teste Qui-quadrado $\left(\chi^{2}\right)$. A TC foi definida como a porcentagem de ovócitos que apresentaram a primeira divisão celular 48 horas após a inseminação in vitro; a TMBL, como a porcentagem de mórulas e blastocistos produzidos a partir dos ovócitos inseminados, nos dias sete, oito e nove de cultura após a inseminação in vitro; e a TECL, como a porcentagem de embriões clivados que eclodiram de sua zonas pelúcidas, a partir do oitavo dia de cultura pós-inseminação in vitro.

\section{Resultados e Discussão}

Houve diferença $(\mathrm{P}<0,01)$ com relação à taxa de clivagem, quando se utilizou sêmen submetido a diferentes diluidores para fecundação in vitro de ovócitos bovinos maturados in vitro. A taxa de clivagem obtida a partir de ovócitos fecundados com sêmen diluído com Tris - gema de ovo foi significativamente inferior $(54,4 \%)$ àquelas obtidas com sêmen diluído contendo lactose - gema de ovo $(66,0 \%)$ ou citrato - gema de ovo $(69,3 \%)$, as quais não diferiram entre si (Tabela 1$)$.

Não houve diferença com relação à taxa de mórulas/blastocistos, independente da base utilizada

Tabela 1 - Taxas de clivagem e mórulas/blastocistos produzidas a partir de ovócitos bovinos maturos fecundados in vitro com sêmen submetidos a diferentes diluidores ${ }^{1}$

Table 1 - Cleavage and morulae/blastocysts rates produced from matured bovine oocytes fertilized in vitro with semen diluted with different extenders ${ }^{1}$

\begin{tabular}{|c|c|c|c|c|c|c|}
\hline \multirow[b]{2}{*}{$\begin{array}{l}\text { Diluidores } \\
\text { Extenders }\end{array}$} & \multirow[t]{2}{*}{$\begin{array}{c}\mathrm{N}^{\circ} \text { de ovócitos } \\
\text { N. of oocytes }\end{array}$} & \multicolumn{2}{|c|}{$\begin{array}{c}\text { Taxa de clivagem } \\
\text { Cleavage rate }^{1} \\
\end{array}$} & \multicolumn{3}{|c|}{$\begin{array}{c}\text { Taxa de mórulas/blastocistos } \\
\text { Morulae/blastocysts rate }\end{array}$} \\
\hline & & $\begin{array}{l}\mathrm{n}^{\circ} \\
\mathrm{n} .\end{array}$ & $\begin{array}{l}\%^{2} \\
\%^{2}\end{array}$ & $\begin{array}{l}\mathrm{n}^{\circ} \\
\mathrm{n} .\end{array}$ & $\begin{array}{l}\%^{2} \\
\%^{2}\end{array}$ & $\begin{array}{l}\%^{3} \\
\%^{3} \\
\end{array}$ \\
\hline $\begin{array}{l}\text { Lactose (LG) } \\
\text { Lactose }\end{array}$ & 347 & 231 & $66,0^{a}$ & 33 & 9,5 & 14,3 \\
\hline $\begin{array}{l}\text { Citrato }(\mathrm{CG}) \\
\text { Citrate }\end{array}$ & 391 & 271 & $69,3^{\mathrm{a}}$ & 40 & 10,2 & 14,8 \\
\hline Tris (TG) & 182 & 99 & $54,4^{\mathrm{b}}$ & 22 & 12,1 & 22,2 \\
\hline Total & 920 & 601 & 65,3 & 95 & 10,3 & 15,8 \\
\hline
\end{tabular}

1 Médias seguidas de letras diferentes na mesma coluna diferem $(P<0,01)$ pelo teste qui-quadrado.

2 Calculada a partir dos ovócitos inseminados.

3 Calculada a partir dos ovócitos clivados.

1 Means followed by different letters in the column differ significantly $(P<.01)$ by chi-square analysis.

2 Calculated as a percentage of oocytes inseminated.

3 Calculated as a percentage of oocytes cleaved. 
para os cálculos: quer seja sobre os ovócitos inseminados, ou sobre os clivados (Tabela 1). As taxas de mórulas/blastocistos obtidas no primeiro e segundo casos foram de 9,5 e 14,3\%; 10,2 e 14,8\%; e 12,1 e $22,2 \%$, para lactose - gema de ovo (LG), citrato - gema de ovo (CG) e tris - gema de ovo (TG), respectivamente. A taxa de eclosão também não diferiu $(\mathrm{P}>0,05)$ entre os diluidores utilizados (Tabela 2), sendo de 4,3; 3,3; e 7,1\%, para LG, CG e TG, respectivamente.

O diluidor à base de Tris produziu taxa de clivagem inferior $(\mathrm{P}<0,05)$ à dos demais diluidores estudados (Tabela 2). Existem duas hipóteses para explicar o ocorrido: a primeira é que existiu grande variabilidade entre as observações do experimento, provavelmente devido ao pequeno número de ovócitos utilizados no tratamento do Tris, quando comparado com os demais tratamentos. Isso pode ter favorecido o resultado negativo com relação à taxa de clivagem para esse tratamento. COELHO et al. (1995) já demonstraram que a reprodutibilidade do sistema de produção in vitro de embriões bovinos é baixa, necessitando de maior número de repetições laboratoriais, pois existem fatores não-controlados, como a utilização de soro nos meios de cultura e cultivo de células para manutenção do desenvolvimento embrionário (GARDNER, 1994) que determinam essas diferenças. Neste trabalho, utilizaram-se somente três repetições por tratamento, sendo que uma repetição do tratamento do Tris foi desconsiderada, em virtude de contaminação fúngica da cultura. Atualmente, as pesquisas têm sido direcionadas para utilização de meios de cultura totalmente definidos (BAVISTER et al., 1992; KESKINTEPE et al., 1995; KESKINTEPE e BRACKETT, 1996; e JAAKMA, et al., 1997) que não contenham substâncias cujos os componentes não-identificados possam mascarar os resultados obtidos a partir das variáveis estudadas.

A outra hipótese é que o diluidor Tris pode ter afetado negativamente as condições de cultura, durante a maturação e fecundação dos ovócitos, sem, entretanto, comprometer o desenvolvimento embrionário após a clivagem, pois, de certa forma, os ovócitos fecundados com sêmen diluído com Tris suportaram as condições de cultura para o desenvolvimento embrionário tanto quanto os outros diluidores testados, já que as taxas de mórulas/blastocistos e eclosão não foram significativas (Tabela 2). Os diluidores à base de Tris não somente produzem o melhor sistema tampão para diluir o ejaculado para congelação, como também têm melhorado a motilidade
Tabela 2 - Taxa de eclosão ${ }^{1}$ obtida a partir de ovócitos bovinos maturos fecundados in vitro com sêmen submetidos a diferentes diluidores ${ }^{2}$

Table 2 - Hacthing rate ${ }^{1}$ from matured bovine oocytes fertilized in vitro with semen diluted with different extenders ${ }^{2}$

\begin{tabular}{lcc}
\hline $\begin{array}{l}\text { Diluidores } \\
\text { Extenders }\end{array}$ & $\begin{array}{c}\text { Ovócitos clivados }\left(\mathrm{n}^{\circ}\right) \\
\text { Oocytes cleaved }(n .)\end{array}$ & $\begin{array}{r}\text { Taxa de eclosão }\left(\mathrm{n}^{\circ}\right)^{2} \\
\text { Hacthing rate }(n .)^{2}\end{array}$ \\
\hline $\begin{array}{l}\text { Lactose }(\mathrm{LG}) \\
\text { Lactose }\end{array}$ & 231 & $4,3(10)$ \\
$\begin{array}{l}\text { Citrato }(\mathrm{CG}) \\
\text { Citrate }\end{array}$ & 271 & $3,3(9)$ \\
$\begin{array}{l}\text { Tris }(\mathrm{TG}) \\
\text { Tris }\end{array}$ & 99 & $7,1(7)$ \\
\hline Total & 601 & $4,3(26)$ \\
\hline
\end{tabular}

1 Calculada a partir dos ovócitos clivados, sendo definida como \% de embriões que eclodiram da zona pelúcida nos dias 8, 9 e 10 após a inseminação in vitro (Dia zero = inseminação).

2 NS $(P>0,05)=$ não diferiram significativamente pelo teste quiquadrado.

1 Calculated from number of oocytes cleaved, defined as a percentage of embryos which hatched from zona pelucida on days 8, 9 and 10 after insemination in vitro (Day $0=$ insemination).

$2 N S(P>.05)=$ no significantly difference by chi-square test.

do sêmen (GRAHAM et al., 1972) e induzido a capacitação espermática dos espermatozóides bovinos (IJAZ et al., 1989) que penetraram em ovócitos de bovinos (HENSLEIGH e HUNTER, 1985) ou em ovócitos de hamsters livres da zona pelúcida (IJAZ e HUNTER, 1989). Considerando os dados da literatura, esperar-se-ia que, neste trabalho, o sêmen diluído com Tris apresentasse melhores taxas de clivagem, quando incubado com ovócitos maturos ou, pelo menos, não a afetasse negativamente. Entretanto, isso não ocorreu, provavelmente devido ao fato de que a forte correlação observada entre fertilidade e motilidade pós-descongelação (LINFORD et al., 1976) é válida apenas para fecundação in vivo, mas não para fecundação in vitro (FIV), e a taxa de clivagem nem sempre é o melhor indicativo da taxa de fecundação.

A primeira hipótese parece ser mais plausível, pois a afirmativa de que o diluidor à base de Tris produziu taxas de clivagem inferiores às dos demais tratamentos provavelmente foi atribuída ao menor número de observações deste tratamento em relação aos demais.

Outro fator que pode interagir com o diluidor do sêmen é o método de preparo dos espermatozóides para fecundação in vitro. Para preservar a capacidade fecundante dos espermatozóides, faz-se necessária a eliminação do plasma seminal, o qual contém fatores que inibem esta capacidade. Embora os vários métodos utilizados para separação dos espermatozóides (PARRISH et al., 1984; ESTIENNE 
et al., 1987; STUBBINGS e WOSIK, 1991; ANZAR e GRAHAM, 1993; e AVERY e GREVE, 1995) também eliminem o diluidor do sêmen, observa-se que, ainda assim, a viabilidade espermática é afetada pelo diluidor e aqueles à base de Tris melhoram a motilidade pós-descongelação do sêmen cujo plasma seminal foi separado por filtração em coluna de sefadex/filtro de troca iônica (ANZAR e GRAHAM, 1995). A eliminação do diluidor do sêmen antes da incubação com os ovócitos parece afetar a fecundação e o início do seu desenvolvimento embrionário (LONERGAN et al., 1994), mas não o desenvolvimento pós-clivagem (LONERGAN et al., 1993; COELHO et al., 1996). De acordo com trabalho em questão, LONERGAN et al. (1994) também observaram que o diluidor do sêmen influi na taxa de clivagem. Entretanto, LONERGAN et al. (1994) constataram diferença no sêmen de apenas um dos seis reprodutores testados, sugerindo possível interação entre o diluidor do sêmen e o reprodutor. Em suma, o diluidor do sêmen não interferiu no desenvolvimento in vitro de embriões bovinos, embora a taxa de clivagem tenha sido afetada.

\section{Conclusões}

O diluidor do sêmen afetou a taxa de clivagem dos ovócitos bovinos, maturados e fecundados in vitro, sendo que o diluidor à base de Tris - gema de ovo produziu valores inferiores aos demais. Entretanto, pesquisas adicionais com maior número de repetições são necessárias para validar estes resultados.

Em contrapartida, o diluidor do sêmen não influenciou o desenvolvimento embrionário in vitro dos ovócitos bovinos após a clivagem. Considerando que, dentro do sistema de produção de embriões in vitro, os parâmetros que traduzem o desenvolvimento embrionário pós-clivagem são mais importantes para serem avaliados, qualquer um dos diluidores testados pode ser utilizado.

\section{Referências Bibliográficas}

ANZAR, M., GRAHAM, E.F. 1995. Effect of filtration on post-thaw quality of bull semen. Theriogenology, 43:439-449.

ANZAR, M., GRAHAM, E.F. 1993. Filtration of bovine semen. I. Development of a Sephadex ion-exchange filter. Anim. Reprod. Sci., 31:187-195.

AVERY, B., GREVE T. 1995. Impact of percoll on bovine spermatozoa used for in insemination Theriogenology, 44:871-878.

BAVISTER, B.D., ROSE-HELLEKANT, T.A., PINYOPUMMINTR, T. 1992. Development of in vitro matured/in vitro fertilized bovine embryos into morulae and blastocysts in defined culture media. Theriogenology, 37:127-146.

CHOI, Y.H., TAKAGI, M., KAMISHITA, H. et al. 1998. Developmental capacity of bovine oocytes matured in two kinds of follicular fluid and fertilized in vitro. Anim. Reprod. Sci., 50:27-33.

COELHO, L.A. Avaliação da motilidade progressiva e da integridade da membrana plasmática de espermatozóides de bovinos para fecundação in vitro. Jaboticabal, SP: FCAV 1993, 96p. Tese (Mestrado em Zootecnia) - Faculdade de Ciências Agrárias e Veterinárias - Universidade Estadual Paulista, 1993.

COELHO, L.A., ESPER, C.R., GARCIA, J.M. The effect of extender on the production of bovine embryos fertilized in vitro. In: INTERNATIONAL CONGRESS ON ANIMAL REPRODUCTION, 13, Sidney, 1996, Proceedings... Austrália, 1996, v.2, p.8-3.

COELHO, L.A., GARCIA, J.M., ESPER, C.R. et al. Reprodutibilidade do sistema de produção de embriões bovinos in vitro (Resultados Preliminares). In: SIMPÓSIO BRASILEIRO DE PESQUISA EM MEDICINA VETERINÁRIA, 1, 1995, São Paulo. Anais... São Paulo: FMVZ/USP, 1995, p.95.

ELMILEIK, A.M.A., MAEDA, T., TERADA, T. 1995. Higher rates of development into blastocyst following the in vitro fertilization of bovine oocytes matured in a medium supplement with the fluid from large bovine follicles. Anim. Reprod. Sci., 38:85-96.

ESTIENNE, M.J. KNIGHT, M.J., BEAL, W.E. 1988. Isolation of a population of intact, highly-motile porcine spermatozoa using a discontinuous bovine serum albumin gradient. Theriogenology, 29:771-778.

FARIN, C.E., HASLER, J.F., MARTUS, N.S. et al. 1997. A comparison of Menezo's B2 and tissue culture medium-199 for in vitro production of bovine blastocysts. Theriogenology, 48:699-709.

GARDNER, D.K. 1994. Mammalian embryo culture in the absence of serum or somatic cell support. Cell Biol. Int., 18:1163-1179.

GRAHAM, E.F., CRABO, B.G., BROWN, K.I. 1972. Effect of some zwitter ion buffers on the freezing and storage of spermatozoa I. Bull. J. Dairy Sci., 55:372-378.

HANZEN, C., GOFFIN, L. 1998. Use of ultrasonography for ovum pick-up (OPU) in the bovine. A review. Ann. Med. Vet., 142:81-91.

HASLER, J.F. 1996. Commercial production of in vitro-derived bovine embryos. Arq. Fac. Vet. UFRGS, 24:117-134. (Supl.)

HENSLEIGH, H.C., HUNTER, A.G. 1985. In vitro maturation of bovine cumulus enclosed primary oocytes and their subsequent in vitro fertilization and cleavage. J. Dairy Sci., 68:1456-1464.

IJAZ, A., HUNTER, A.G. 1989. Induction of bovine sperm capacitation by Test-yolk semen extender. J. Dairy Sci., 72:2683-2690.

IJAZ, A., HUNTER, A.G., GRAHAM, E.F. 1989. Indentification of the capacitating agent for bovine sperm in egg yolk-TEST semen extender. J. Dairy Sci., 72:2700-2706.

ING, R.M.Y., LI, D.Q., HARDING, A.M. et al. 1991. A comparison of swim-down and swim-up methods for extraction of high motility sperm. Fertil. Steril., 55(4):817-819.

JAAKMA, U, ZHANG, B.R., LARSSON, B. et al. 1997. Effects of sperm treatmens on the in vitro development of bovine oocytes in semidefined and defined media. Theriogenology, 
48:711-720.

KESKINTEPE, L., BRACKETT, B.G. 1996. In vitro developmental competence of in vitro-matured bovine oocytes fertilized and cultured in completely defined media. Biol. Reprod., 55:333-339.

KESKINTEPE, L., BURNLEY, C.A., BRACKETT, B.G. 1995. Production of viable bovine blastocysts in defined in vitro conditions. Biol. Reprod., 52:1410-1417.

LINFORD, E., GLOVER, F.A., BISHOP, C. et al. 1976. The relationship between semen evaluation methods and fertility in the bull. J. Reprod. Steril., 47:283-291.

LONERGAN, P., KOMMISRUD, E., HAFNE, A.L. 1994. Comparison of two extenders in terms of in vitro development of bovine embryos following IVF. Acta Vet. Scand., 35:321327.

LONERGAN, P., HAFNE, A.L., FARSTAD, W. et al. 1993. Effect of semen extender on in vitro development of bovine embryos following IVF. Reprod. Dom. Anim., 28:174-175.

LOONEY, C.R., LINDSEY, B.R., GONSETH, C.L. et al. 1994. Comercial aspects of oocyte retrieval and in vitro fertilization (IVF) for embryo production in problem cows. Theriogenology, 41:67-72.
PARRISH, J.J., PARRISH, J.L., FIRST, N.L. 1984. Effect of swimup separation and heparin pretreatment of frozen thawed spermatozoa on in vitro fertilization of bovine oocytes. Biol. Reprod., 30:112. (Abstract).

STROUD, B.K., MYERS, M.W. 1993. Clinical results in a comercial IVF facility. Ars Veterinária, 9:105-230.

STUBBINGS, R.B., WOSIK, C.P. 1991. Glass wool versus swim up separation of bovine spermatozoa for in vitro fertilization. Theriogenology, 35:276. (Abstract).

Recebido em: 12/01/99

Aceito em: 17/09/99 